\title{
Great Expectations: The Relationship Between Future Time Perspective, Learning from Others, and Employability
}

\author{
Dominik E. Froehlich $^{1}$ - Simon A.J. Beausaert ${ }^{2,3}$. \\ Mien S.R. Segers ${ }^{3}$
}

Received: 12 June 2014 / Accepted: 16 April 2015 /

Published online: 10 May 2015

(C) The Author(s) 2015. This article is published with open access at Springerlink.com

\begin{abstract}
Employees in countries with advanced industrial economies need to continuously develop their competences to sustain their employability - that is, to have a set of competences that enables them to maintain or find an adequate job. But how should efforts to enhance employability progress in the context of the demographic shift? Previous research suggests that employees' perspective about their future working life may influence their motivation to engage in learning activities. The study reported and discussed here investigates how employees' perceptions of the future as a time of opportunities and limitations affects their engagement in learning from others and, in turn, their employability. We tested our model empirically in two Austrian consultancies $(n=167)$. We find that focus on opportunities in the future explains engagement in learning from others and, subsequently, differences in employability. The informants' perspectives about the future may be a helpful alternative to the measurement of chronological age, which is problematic from a conceptual point of view.
\end{abstract}

Keywords Employability Future time perspective $\cdot$ Learning from others

The populations of most countries with advanced industrial economies are aging (OECD 2012). Policymakers react to this situation by encouraging longer working

Dominik E. Froehlich

dom.froehlich@gmail.com

1 Department of Educational Research and Development, Maastricht University, P.O. Box 616, 6200 MD Maastricht, The Netherlands

2 Faculty of Psychology and Educational Sciences, Université Catholique de Louvain-la-Neuve, Louvain-la-Neuve, Belgium

3 Department of Educational Research and Development, Maastricht University, Maastricht, The Netherlands 
lives (e.g., later retirement; European Commission 2012) to maintain the viability of their social welfare systems (Walker and Maltby 2012) and to avert the loss of workplace skills and knowledge caused by the large number of workers retiring in the upcoming years (Midtsundstad and Bogen 2014). This situation is exacerbated by companies' aging workforces. For example, the German car manufacturer BMW estimates that the number of workers older than 50 doubles between 2010 and 2020 (Anderson 2013). At the same time, increasing global competition and accelerating rates of innovation make work requirements more and more dynamic. But how do these two trends - the demographic shift and the increasingly fast-paced business world - relate to each other? After all, older employees' ability to adapt to such a dynamic environment is often doubted by employers, although the evidence is ambiguous (Finkelstein et al. 2015). In a similar vein, research indicates that older employees are disproportionally more often subject to layoffs during restructuring measures (Kim and Mo 2014) and have greater difficulty to find a job should they lose their current employment (Ahmed et al. 2012; Albert et al. 2011). Put differently, older people's competence to fulfill, acquire, or create work for themselves - their employability (Van der Heijde and Van der Heijden 2006) - is questioned, albeit often based on societal sentiments rather than actual evidence (cf. Meyers et al. 2010).

But how should efforts to enhance employability progress in the context of an aging workforce? Research suggests that learning activities such as working on developmental tasks, networking, or attending trainings are adequate means of improving individuals' employability (Froehlich et al. 2014a; Van der Heijden et al. 2009; Van der Klink et al. 2014; Van Emmerik et al. 2012). Previous studies have found that learning from others - in contrast to the learning opportunities offered in trainings - is especially important for older employees (Billett 2011; Froehlich et al. 2014b). The hypothesized reason for this is that learning from others is less dependent on employers' resources, which are often not accessible for older employees. As mentioned by Billett and Van Woerkom (2008), younger employees are often privileged in terms of receiving support and opportunities for learning in the workplace. Older employees, therefore, need to develop their own ways of learning and building their competences. In sum, several studies find significant relationships between learning activities and employability in the context of an aging workforce. But they do not explain why some older employees keep developing their employability and others do not.

So, this leads to the question about which personal factors play a role when it comes to undertaking learning activities for enhancing employees' employability in the context of the demographic shift. Previous research suggests that future time perspective is an important concept when studying older people's motivation to learn (Bal and Jansen 2015; Gegenfurtner and Vauras 2012; Kooij et al. 2014. Future time perspective refers to people's perceptions of how many opportunities (i.e., opportunity focus) and limitations (i.e., limitation focus) are ahead of them in their (working) life (Cate and John 2007). This perspective has been linked to, for instance, a focus on promotions (Kooij et al. 2014), work motivation (De Lange et al. 2011), or work performance (Zacher et al. 2010). The relationship between individuals' future time perspective and their employability, however, has not yet been empirically researched (Raemdonck et al. 2015). Therefore, the aim here is to investigate how employees' future time perspectives are linked to their employability through learning from others. We extend previous research that has connected learning activities to employability (Froehlich 
et al. 2014b; Van der Heijden et al. 2009) by adding future time perspective as an antecedent for explaining their learning. This additional information may be essential for understanding why some employees lose in employability, while others are able to maintain or even extend their competences.

\section{Competence-Based Employability}

Being employable comprises having a set of competences that enables people to fulfill, acquire, or create work for themselves (Van der Heijde and Van der Heijden 2006). The advantage of this competence-based definition is that in today's times of fluctuating labor market demands, such competences provide a relatively stable basis for that employability. This, however, does not mean that employability is a static concept: Employability may increase or decrease dynamically, as employees can develop or lose their workplace competences (Sanders and De Grip 2004). Van der Heijde and Van der Heijden (2006) privileges occupational expertise as an important prerequisite for employability. Additionally, employability requires more generic social and adaptive competences (Rodriguez et al. 2002; Wright and Snell 1998). Employees need to proactively screen the environment and prepare themselves for potential changes in job and career requirements and conditions (i.e., anticipation and optimization) and adapt to them (i.e., personal flexibility) (Fugate et al. 2004). Furthermore, identification with the organization's goals and the ability to work together with others (i.e., corporate sense) are beneficial (Podsakoff et al. 1997). Last, Van der Heijde and Van der Heijden (2006) name balance as a key competence. This comprises employees' ability to weigh employer's interests against theirs (e.g., balance of working and learning). In sum, these five competences should allow employees to fulfill, acquire, or create work for themselves.

Employees, however, act based on their own perceptions, not just on the bases of some prescriptions of how they should act. Therefore, it is necessary to account for employees' subjective ratings of their competences in this study. This view is consistent with earlier research (Fugate et al. 2004; Van Emmerik et al. 2012). Kinnunen et al. (2011), for instance, derive the importance of self-perceived employability from Lazarus and Folkman's (1984) transactional stress theory. These theorists argue that employees who perceive themselves as employable feel less threatened by the environment, experience less strain (Berntson and Marklund 2007), and engage more in their work (De Cuyper et al. 2008).

\section{Learning from Others: Proactive Feedback and Help Seeking}

Much recent research about learning and work has focused on learning opportunities outside education and training institutions (Kyndt and Baert 2013). For instance, this includes learning by doing, having discussions with colleagues, or engaging in reflection (Marsick 2009). Several studies suggest that these learning activities are more efficient than attending seminars and workshops of education and training institutions (Berings et al. 2008; Billett 2002; Eraut 2007; Van der Heijden et al. 2009). The social aspect of learning in the workplace plays an especially important role (Billett 1995; 
Boud and Middleton 2003; Eraut 2007). Specifically, seeking feedback and help from others are important means of learning in the workplace (Bamberger 2009) and may help to develop the competences needed to stay employable. Feedback seeking is the proactive search for information targeted at evaluating and reflecting upon work processes and the self (Anseel et al. 2007). This does not require a specific problem and may be rooted in motives such as achieving a goal or protecting one's ego (Ashford et al. 2003). Proactive feedback-seeking behavior has been mostly related to positive outcomes, such as goal attainment (Ammons 1956) and performance (Kluger and DeNisi 1996). More recent research suggests that the feedback quality and not so much the quantity of it is important for learning and development (Van der Rijt et al. 2012).

Help seeking means the proactive search for assistance from others to solve a specific problem. Help seekers are, therefore, required to locate and define a problem, to think about persons who are accessible and knowledgeable regarding this problem, and to establish contact with these persons (Lee 1997). Help seeking has a long research tradition in the field of academic learning (Järvelä 2011; Mäkitalo-Siegl and Fischer 2011). There, it is seen as an essential method to engage learners cognitively, behaviorally, and emotionally (Pintrich and Zusho 2002) and to contribute to resilience, efficacy, and learning (Karabenick and Newman 2006; Karabenick 1998).

Learning from others in terms of proactive feedback and help-seeking may enhance employees' employability. For instance, employees may increase their knowledge about a relevant subject (i.e., enhance occupational expertise) or about processes in the organization (i.e., corporate sense). They may learn about trends (i.e., anticipation and optimization) that are central to effective work performance and how to react towards them (i.e., personal flexibility). Finally, by getting relevant and useful information, they may deem their working and learning to be more in balance. Previous empirical studies find positive relationships between learning from others and employability. For instance, Van der Heijden et al. (2009) have researched the relationship among non-academic university employees' networking behavior and their employability. They find that networking within and outside the home organization relates positively to employability. Moreover, the evidence suggests that interaction with one's supervisor may improve balance and corporate sense. The study was largely replicated among academic staff members by Van der Klink et al. (2014). There, networking enhanced anticipation and optimization, personal flexibility, and corporate sense. Additionally, Van der Rijt et al. (2012) report feedback seeking to increase perceived career development among employees in the financial sector. Froehlich et al. (2014a, b) also find that proactive search for information, feedback, and help improves occupational expertise, anticipation and optimization, and personal flexibility. Therefore, we hypothesize that learning from others in terms of feedback and help seeking stands to improve employability. This then leads to our hypothesis:

Hypothesis 1 Proactive learning from others positively affects employability in terms of occupational expertise, anticipation and optimization, personal flexibility, corporate sense, and balance. 


\section{Future Time Perspective}

According to the socioemotional selectivity theory (Carstensen et al. 1999), individuals select and pursue their goals in alignment with their (working) life's time horizon. Specifically, people with a limited future time perspective seek emotional well-being and short-term benefits. Conversely, people viewing time as open-ended value the acquisition of knowledge and skills more (Carstensen 2006). Cate and John (2007) later found that adults might experience limitations and opportunities simultaneously. For instance, middle-aged adults become aware of physical decline (Lachman et al. 1994), but also experience gains in confidence and generativity (Miner-Rubino et al. 2004; Stewart et al. 2001). A one-dimensional conceptualization of future time perspective does not consider this. Therefore, Cate and John (2007) developed a two-factor solution that distinguishes in how far the future time is perceived as a time of opportunities and limitations.

Little empirical evidence exists for the relationship between future time perspective and learning from others. However, we know from educational psychology that an extensive future time perspective may be associated with, for instance, higher engagement (Horstmanshof and Zimitat 2007), an increased likelihood of completing tasks (Bembenutty and Karabenick 2004), increased persistence to study, and better academic performance (De Volder and Lens 1982). Likewise, Janeiro and Marques (2010) find future time orientation to be positively related to career attitudes among Portuguese pupils (Creager 2011). Simons et al. (2004) and Miller and Brickman (2004) argue that the perception of more opportunities ahead increases the instrumentality of individuals' learning behavior. This, in turn, affects the motivation to learn. In a more general sense, Lang and Carstensen (2002) find effects of future time perspective on the composition of adults' social networks. Specifically, individuals who perceive the future as limited prefer emotional goals and, thus, are more likely to connect to relatives and formal partners. Contrarily, individuals who have an expansive perception of the future prefer to interact with knowledgeable or controversial partners to fulfill their desire for growth. This difference is attributable to the different goals associated with opportunity focus and limitation focus and might indicate an influence of opportunity focus and limitation focus on learning from others. We hypothesize that opportunity focus stimulates learning from others in terms of feedback and help seeking and, in turn, strengthens employees' employability. Conversely, we hypothesize that limitation focus deters learning from others and hence weakens employees' employability.

Hypothesis 2 Opportunity focus positively affects employability in terms of occupational expertise, anticipation and optimization, personal flexibility, corporate sense, and balance via proactive learning from others.

Hypothesis 3 Limitation focus negatively affects employability in terms of occupational expertise, anticipation and optimization, personal flexibility, corporate sense, and balance via learning from others.

Figure 1 displays the research model. 


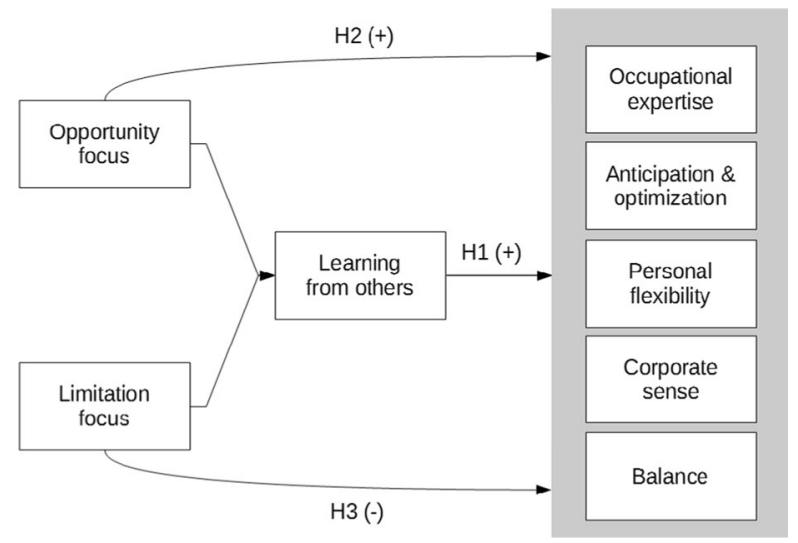

Fig. 1 Conceptual model

\section{Methods}

\section{Participants}

We sent electronic questionnaires to 215 randomly selected employees of two Austrian consultancies. The first organization generates its profits predominantly in the domain of information technology $(n=77$; response rate $=72 \%)$. The second organization is a not-for-profit organization and offers a wider array of consulting services, including, for instance, consultations about international law and policy $(n=90$, response rate $=83 \%)$. In both organizations, the respondents work in project teams to provide consulting services directly to their clients. Consultancies are an interesting setting for this study due to the industry-specific demand for employability (Petersitzke and Hristozova 2006). For example, consulting knowledge needs to very current and yet it depreciates rapidly (Kubr 2002). In addition, consultants need to adapt quickly to new clients and their different structures and cultures. Since the respondents of both organizations are similar in terms of type of work and the national and professional culture they are embedded in, we merged the two samples for the analyses. The respondents were 18 to 59 years old $(\mathrm{M}=40.80, \mathrm{SD}=9.88) .93(56 \%)$ have obtained a higher education degree; $86(52 \%)$ were female. Analysis of variance (ANOVA) showed a difference between the samples in terms of gender $(\mathrm{F}(1,165)=11.58, p \leq 0.01)$, which can be explained by the traditionally male-dominated IT sector. No differences were found for age or degrees from higher education.

\section{Instruments}

We gauged the dimensions of employability using Van der Heijde and Van der Heijden's (2006) instrument of 47 items. In line with our conceptualization of selfappraised employability, respondents assessed their own employability on a 5-point Likert-scale $(1=$ strongly disagree, $5=$ strongly agree $)$. We randomly assigned each item to one of three parcels per dimension to achieve a better relation between the number of parameters and the given sample size in the analyses (Little et al. 2002). This 
model achieved good fit; all scales achieved satisfactory Cronbach's alphas. Table 1 shows fit indices, reliability estimates, and sample items.

We assessed opportunity focus and limitation focus using Lang and Carstensen's (2002) 10-item future time perspective scale, which was reworded to refer to the working life. Respondents answered on a 5-point Likert-scale $(1=$ strongly disagree, 5 = strongly agree). The two-factor solution proposed by Cate and John (2007) fit our data better than a one-factor or three-factor solution; the reliabilities are acceptable (Table 1).

We used Froehlich et al. (2014a, b) scales of feedback and help-seeking behaviors from supervisors and colleagues to measure learning from others. Respondents answered on a 5-point Likert-scale ( $1=$ almost never, 5 = very often $)$; all eight items were collapsed into one scale. We used three parcels to identify learning from others. The scale achieved satisfactory reliability; the model is just identified (Table 1).

We used chronological age and hours spent in formal education activities as covariates in our model. We asked for both using open questions.

\section{Analyses}

We checked and confirmed that the dataset does not contain any missing data. Then, we explored the relations between the variables in bivariate correlation analyses. Last, we tested the hypotheses using structural equation modeling using Maximum Likelihood estimation in Mplus 7.11 (Muthén and Muthén 2012). Model fit was assessed using the comparative fit index (CFI, acceptable if $\geq 0.90$ ), the root mean square error of

Table 1 Overview over the scales used

\begin{tabular}{|c|c|c|c|c|}
\hline Scale & Items & $\alpha$ & Sample item & Model fit \\
\hline $\begin{array}{l}\text { Occupational } \\
\text { expertise }\end{array}$ & 15 & 0.92 & $\begin{array}{l}\text { I consider myself competent to engage } \\
\text { in in-depth, specialist discussions } \\
\text { in my job domain. }\end{array}$ & \multirow{5}{*}{$\begin{array}{l}\mathrm{CFI}=0.95, \\
\mathrm{RMSEA}=0.07, \\
\mathrm{SRMR}=0.06, \\
\chi^{2} / \mathrm{df}=145 / 80= \\
\quad 1.81\end{array}$} \\
\hline $\begin{array}{r}\text { Anticipation \& } \\
\text { optimization }\end{array}$ & 8 & 0.74 & $\begin{array}{l}\text { I take responsibility for maintaining } \\
\text { my labor market value. }\end{array}$ & \\
\hline Personal flexibility & 8 & 0.77 & $\begin{array}{l}\text { I adapt to developments within } \\
\text { my organization. }\end{array}$ & \\
\hline Corporate sense & 7 & 0.80 & $\begin{array}{l}\text { I am involved in achieving my } \\
\text { organization's mission. }\end{array}$ & \\
\hline Balance & 9 & 0.71 & My working, learning, and living are in harmony. & \\
\hline Opportunity focus & 7 & 0.91 & Many work opportunities await me in the future. & \multirow{2}{*}{$\begin{array}{l}\mathrm{CFI}=0.97, \\
\mathrm{RMSEA}=0.07, \\
\mathrm{SRMR}=0.04, \\
\chi^{2} / \mathrm{df}=21 / 14=1.77\end{array}$} \\
\hline Limitation focus & 3 & 0.68 & $\begin{array}{l}\text { I have the sense that my time in the } \\
\text { working life is running out. }\end{array}$ & \\
\hline Learning from others & 8 & 0.79 & $\begin{array}{l}\text { Getting help would be one of the first } \\
\text { things I would do if I were having } \\
\text { trouble at work. }\end{array}$ & $\begin{array}{l}\mathrm{CFI}=1.00, \\
\mathrm{RMSEA}=0.00, \\
\mathrm{SRMR}=0.00, \\
\chi^{2} / \mathrm{df}=- \\
\quad \text { (just identified) }\end{array}$ \\
\hline
\end{tabular}

All scales were measured using 5-point Likert scales. All factor loadings of the measurement models were $\geq$ 0.70 
approximation (RMSEA, acceptable if $\leq 0.07$ ), the standardized root mean squared residual (SRMR, acceptable if $\leq 0.08$ ), and the ratio of $\chi^{2}$ to the degrees of freedom (acceptable if $\leq 3.00$; Hoyle 1995; Hu and Bentler 1999).

\section{Results}

Table 2 presents findings characterized by medium to strong positive correlations among the dimensions of employability $(\mathrm{r}=0.28$ to $0.59, p<0.01)$, strong negative correlations of opportunity focus with limitation focus $(\mathrm{r}=-0.64, p<0.01)$ and chronological age $(\mathrm{r}=-0.70, p<0.01)$, and positive correlations of learning from others with the dimensions of employability $(\mathrm{r}=0.17, p<0.05$ to $\mathrm{r}=0.31, p<0.01)$. These findings are in line with our hypotheses.

The structural equation modeling analyses showed acceptable model fit: $\mathrm{CFI}=0.90$, $\mathrm{RMSEA}=0.07, \mathrm{SRMR}=0.07$, and $\chi^{2} / \mathrm{df}=505 / 287=1.76$. All factor loadings of the measurement model were $\geq 0.70$. In our sample, learning from others positively affects anticipation and optimization $(\mathrm{B}=1.30,99 \% \mathrm{CI}[0.12,6.06]$; see Table 3), personal flexibility $(B=1.45,99 \% \mathrm{CI}[0.27,6.47])$, corporate sense $(\mathrm{B}=1.36,99 \% \mathrm{CI}[0.26$, $7.41]$ ), and balance $(B=0.70,99 \% \mathrm{CI}[0.16,4.19])$. This gives partial support to Hypothesis 1.

We also noted effects of chronological age on occupational expertise $(\mathrm{B}=0.01,95 \%$ $\mathrm{CI}[>0.00,0.02])$ and corporate sense $(\mathrm{B}=0.02,99 \% \mathrm{CI}[>0.00,0.07])$. Attending formal learning activities and the employing organization did not cause significant differences.

We found indirect effects of opportunity focus via learning from others on anticipation and optimization $(\mathrm{B}=0.34,95 \% \mathrm{CI}[0.02,2.25])$ and balance $(\mathrm{B}=0.18,95 \%$ $\mathrm{CI}[0.05,1.54])$. Furthermore, we found weaker effects on personal flexibility $(\mathrm{B}=0.37$, $90 \% \mathrm{CI}[0.11,0.76])$ and corporate sense $(\mathrm{B}=0.35,90 \% \mathrm{CI}[0.11,0.89])$. This gives partial support to Hypothesis 2. Conversely, we found no indirect effects of limitation focus. Thus, Hypothesis 3 receives no support.

\section{Discussion}

We set out to investigate how opportunity focus and limitation focus influence employability via learning from others in terms of feedback and help seeking. This is important, because the role of personal factors for the enhancement of employability in the context of the demographic shift has received little attention so far (Froehlich et al. 2014a; Raemdonck et al. 2015). This information may be crucial to understand the different trajectories of older employees' employability. Why do some employees manage to stay on top of current developments while others fail to advance their employability? We hypothesized that opportunity focus has positive indirect effects on employability via learning from others, while limitation focus has negative indirect effects. We have found positive relationships between learning from others and four dimensions of employability: anticipation and optimization, personal flexibility, corporate sense, and balance. This is consistent with previous research (Froehlich et al. 2014b; Van der Heijden et al. 2009; Van der Klink et al. 2014) and supports the claim 


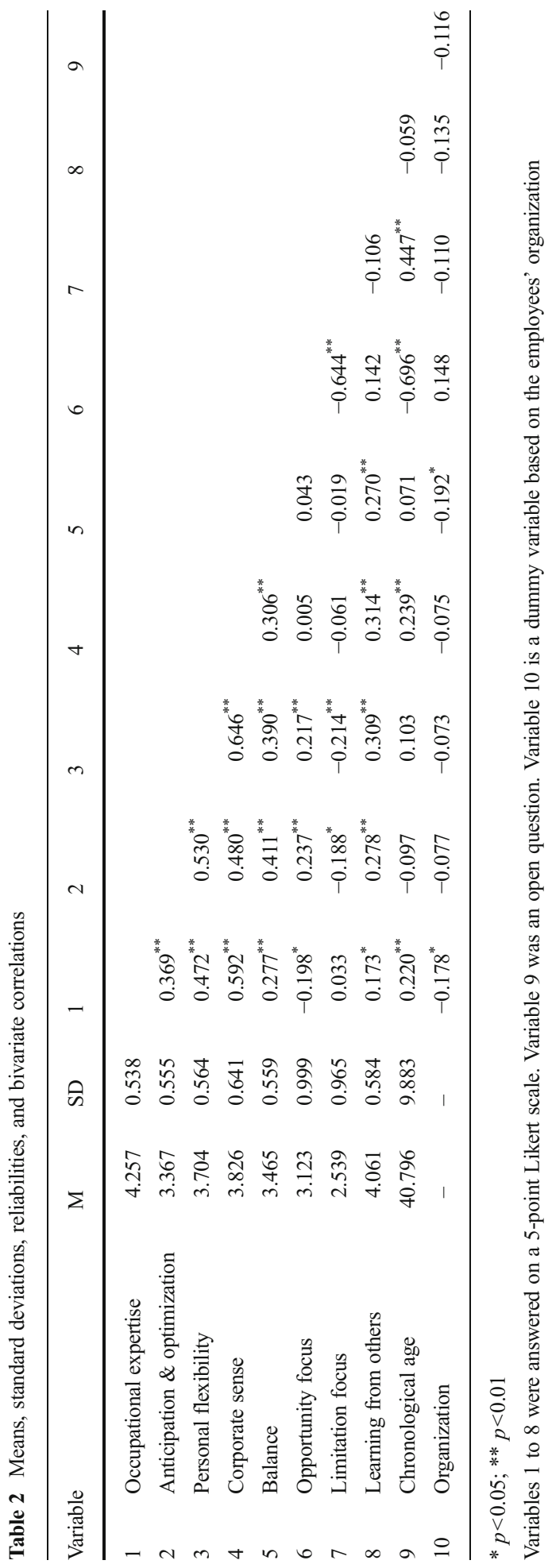


Table 3 Structural equation modeling results showing the unstandardized coefficients

\begin{tabular}{lclllr}
\hline & $\begin{array}{l}\text { Occupational } \\
\text { expertise }\end{array}$ & $\begin{array}{l}\text { Anticipation \& } \\
\text { optimization }\end{array}$ & $\begin{array}{l}\text { Personal } \\
\text { flexibility }\end{array}$ & $\begin{array}{l}\text { Corporate } \\
\text { sense }\end{array}$ & Balance \\
\hline Learning from others & 0.310 & $1.303^{* *}$ & $1.445^{* *}$ & $1.362^{* *}$ & $0.699^{* *}$ \\
Formal learning & 0.003 & 0.004 & 0.002 & 0.003 & 0.000 \\
Organization & -0.132 & 0.030 & 0.174 & 0.129 & -0.020 \\
Chronological age & $0.013^{*}$ & -0.01 & 0.009 & $0.020^{* *}$ & 0.006 \\
Indirect effects via learning from others & & & & $0.180^{*}$ \\
Opportunity focus & 0.080 & $0.335^{*}$ & 0.372 & 0.351 & 0.009 \\
Limitation Focus & 0.004 & 0.017 & 0.018 & 0.017 & \\
\hline
\end{tabular}

$* p<0.05$

that learning activities in general and learning from others in particular are apt means of developing employability. Opportunity focus, which stimulates learning from others, has been found to have indirect positive effects on employability. In other words, the perceptions of many opportunities in one's future working life triggers learning from others and, in turn, helps employees to enhance their employability. Given the strong correlations between chronological age and future time perspective found in previous research (e.g., Lang and Carstensen 2002), this finding has important implications for the development of employability in the context of an aging workforce.

First, the findings have implications for further research. Future time perspective is an interesting personal factor to study the development of employability of an aging workforce. This is important, as the low employment rates among older people (OECD 2014) raise questions about the learning behavior and employability of older employees. However, previous research in the fields of learning and employability struggles to answer these questions, as employee age and the change in future time perspective associated with it have often been ignored. Future research should be more sensitive to the changes associated with aging and their effects on learning within organizations. This calls for the inclusion of other conceptualizations of age, next to chronological age (Maurer et al. 2003; Raemdonck et al. 2015), which is often criticized on the grounds of two conceptual problems. First, chronological age is used as a proxy measure for many factors related to aging, such as physical changes, agerelated stereotypes, or effects specific to a certain cohort (Hall et al. 2007). These effects are difficult to disentangle from each other. Second, the more experiences people have made in their lives, the more heterogeneous they are (Carstensen 2006; Staudinger and Bowen 2011). This weakens the predictive power of chronological age. The study presented here has shown that future time perspective may be an interesting alternative to the use of chronological age as a predictor for engagement in learning activities and employability. Older employees, after all, are not a homogeneous group of people (Bal and Jansen 2015) - personal factors matter.

Second, implications for practice may be derived from the role that opportunity focus and limitation focus play in our model. The findings suggest that it is an essential task of human resource development managers to develop an opportunity focus across the workforce. Unfortunately, organizational research offers little advice of how this 
may be accomplished. But research in other fields, such as education and health science, hints at potential solutions. For instance, clarifying the instrumentality of any learning activity for future success beforehand (Simons et al. 2004), communicating the role of work-related learning and personal goals (Phalet et al. 2004), or facilitating long-term planning (Gellert et al. 2012) might help. Also, the use of long-term personal development plans may support this development (Beausaert et al. 2011). As opportunity focus is a function of chronological age, it may also be relevant to educate against ageism, for instance by fostering high-quality intergenerational contact (Iweins et al. 2013) or offering age awareness trainings (Armstrong-Stassen and Templer 2005).

Future research may improve and extend this study in terms of measurement and generalizability. In this study, the employees self-assessed their employability. But previous research has found that employees rate themselves higher than their employers do (Van der Heijde and Van der Heijden 2006) and higher than their labor market success would suggest (Patrickson and Ranzijn 2003). Our conceptualization of employability as perceived employability, however, is in line with previous research (Kinnunen et al. 2011; Van Emmerik et al. 2012). Nevertheless, to test for common method bias (Podsakoff and Organ 1986), further research may include also other sources for assessing the variables.

We have executed this study in the consultancy sector. We believe that the industryspecific demands for employability (Petersitzke and Hristozova 2006) make it an interesting setting for our study. At the same time, these industry-specific affordances may limit the generalizability of this research's finding. Thus, further research may replicate this study in different sectors.

In conclusion, the study reported and discussed here offers first evidence for an indirect effect of opportunity focus on employability via learning from others. It presents future time perspective as an alternative variable to the use of chronological age to research learning and employability in the context of an aging workforce. Furthermore, it implies that the concept of future time perspective may also be addressed by human resource practitioners in order to prepare their company for an older, but still highly employable, workforce.

Funding This research project was funded by Stichting A+O Metalektro (http://www.ao-metalektro.nl/).

Open Access This article is distributed under the terms of the Creative Commons Attribution 4.0 International License (http://creativecommons.org/licenses/by/4.0/), which permits unrestricted use, distribution, and reproduction in any medium, provided you give appropriate credit to the original author(s) and the source, provide a link to the Creative Commons license, and indicate if changes were made.

\section{References}

Ahmed, A. M., Andersson, L., \& Hammarstedt, M. (2012). Does age matter for employability? A field experiment on ageism in the Swedish labour market. Applied Economics Letters, 19(4), 403-406. doi:10. 1080/13504851.2011.581199.

Albert, R., Escot, L., \& Fernández-Cornejo, J. A. (2011). A field experiment to study sex and age discrimination in the Madrid labour market. International Journal of Human Resource Management, 22(2), 351375. doi:10.1080/09585192.2011.540160.

Ammons, R. B. (1956). Effects of knowledge of performance: a survey and tentative theoretical formulation. Journal of General Psychology, 54(2), 279-299. doi:10.1080/00221309.1956.9920284. 
Anderson, L. B. (2013). How frames present BMW as embracing an aging workforce. Public Relations Review, 39(5), 484-490. doi:10.1016/j.pubrev.2013.02.003.

Anseel, F., Lievens, F., \& Levy, P. E. (2007). A self-motives perspective on feedback-seeking behavior: linking organizational behavior and social psychology research. International Journal of Management Reviews, 9(3), 211-236. doi:10.1111/j.1468-2370.2007.00210.x.

Armstrong-Stassen, M., \& Templer, A. (2005). Adapting training for older employees: the Canadian response to an aging workforce. Journal of Management Development, 24(1), 57-67. doi:10.1108/ 02621710510572353.

Ashford, S. J., Blatt, R., \& VandeWalle, D. (2003). Reflections on the looking glass: a review of research on feedback-seeking behavior in organizations. Journal of Management, 29(6), 773-799. doi:10.1016/ S0149-2063(03)00079-5.

Bal, P. M., \& Jansen, P. G. W. (2015). Idiosyncratic Deals for Older Workers: Increased Heterogeneity among Older Workers Enhance the Need for I-Deals. In P. M. Bal, D. T. A. M. Kooij, \& D. M. Rousseau (Eds.), Aging Workers and the Employee-Employer Relationship (pp. 129-144). Cham: Springer Netherlands. doi:10.1007/978-3-319-08007-9_8.

Bamberger, P. A. (2009). Employee Help-Seeking: Antecedents, Consequences and new Insights for Future Research. In J. J. Martocchio \& H. Liao (Eds.), Research in Personnel and Human Resource Management (Vol. 28, pp. 49-98). Bingley: Emerald Group Publishing. doi:10.1108/S0742-7301(2009) 0000028005.

Beausaert, S. A. J., Segers, M. S. R., Van der Rijt, J., \& Gijselaers, W. H. (2011). The Use of Personal Development Plans (PDPs) in the Workplace: A Literature Review. In P. Van den Bossche, W. H. Gijselaers, \& R. G. Milter (Eds.), Building Learning Experiences in a Changing World (Vol. 3, pp. 235-265). Dordrecht: Springer Netherlands. doi:10.1007/978-94-007-0802-0.

Bembenutty, H., \& Karabenick, S. A. (2004). Inherent association between academic delay of gratification, future time perspective, and self-regulated learning. Educational Psychology Review, 16(1), 35-57. doi: 10.1023/B:EDPR.0000012344.34008.5c.

Berings, M. G. M. C., Poell, R. F., \& Simons, P. R.-J. (2008). Dimensions of on-the-job learning styles. Applied Psychology: An International Review, 57(3), 417-440. doi:10.1111/j.1464-0597.2008.00362.x.

Berntson, E., \& Marklund, S. (2007). The relationship between employability and subsequent health. Work and Stress, 21(3), 279-292. doi:10.1080/02678370701659215.

Billett, S. (1995). Workplace learning: its potential and limitations. Education and Training, 37(4), 20-27.

Billett, S. (2002). Towards a workplace pedagogy: guidance, participation and engagement. Adult Education Quarterly, 53(1), 27-43. doi:10.1177/074171302237202.

Billett, S. (2011). Promoting lifelong employability for workforce aged over 45: Singaporean Workers' perspectives. International Journal of Continuing Education and Lifelong Learning, 3(2), 57-73.

Billett, S., \& Van Woerkom, M. (2008). Personal epistemologies and older workers. International Journal of Lifelong Learning, 27(3), 333-348.

Boud, D., \& Middleton, H. (2003). Learning from others at work: communities of practice and informal learning. Journal of Workplace Learning, 15(5), 194-202. doi:10.1108/13665620310483895.

Carstensen, L. L. (2006). The influence of a sense of time on human development. Science, 312(5782), 19131915. doi:10.1126/science. 1127488.

Carstensen, L. L., Isaacowitz, D. M., \& Charles, S. T. (1999). Taking time seriously: a theory of socioemotional selectivity. American Psychologist, 54(3), 165-181. doi:10.1037/0003-066X.54.3.165.

Cate, R. A., \& John, O. P. (2007). Testing models of the structure and development of future time perspective: maintaining a focus on opportunities in middle Age. Psychology and Aging, 22(1), 186-201. doi:10.1037/ 0882-7974.22.1.186.

Creager, M. F. S. (2011). Practice and research in career counseling and development - 2010. Career Development Quarterly, 59(4), 482-528. doi:10.1002/j.2161-0045.2011.tb00973.x.

De Cuyper, N., Bernhard-Oettel, C., Berntson, E., De Witte, H., \& Alarco, B. (2008). Employability and employees' well-being: mediation by job insecurity. Applied Psychology, 57(3), 488-509.

De Lange, A. H., Bal, P. M., Van der Heijden, B. I. J. M., De Jong, N., \& Schaufeli, W. B. (2011). When I'm 64: psychological contract breach, work motivation and the moderating roles of future time perspective and regulatory focus. Work \& Stress, 25(4), 338-354. doi:10.1080/02678373.2011.632610.

De Volder, M. L., \& Lens, W. (1982). Academic achievement and future time perspective as a cognitivemotivational concept. Journal of Personality and Social Psychology, 42(3), 566-571. doi:10.1037//00223514.42.3.566.

Eraut, M. (2007). Learning from other people in the workplace. Oxford Review of Education, 33(4), 403-422. doi:10.1080/03054980701425706. 
European Commission. (2012). An Agenda for Adequate, Safe and Sustainable Pensions. Brussels: European Commission.

Finkelstein, L. M., King, E. B., \& Voyles, E. C. (2015a). Age metastereotyping and cross-age workplace interactions: a meta view of age stereotypes at work. Work, Aging and Retirement, 1(1), 26-40. doi:10. 1093/workar/wau002.

Froehlich, D. E., Beausaert, S. A. J., \& Segers, M. S. R. (2014). Age, employability and the role of learning activities and their motivational antecedents: a conceptual model. International Journal of Human Resource Management, 1-15. doi:10.1080/09585192.2014.971846

Froehlich, D. E., Beausaert, S. A. J., Segers, M. S. R., \& Gerken, M. (2014b). Learning to stay employable. Career Development International, 19(5), 508-525. doi:10.1108/CDI-11-2013-0139.

Fugate, M., Kinicki, A. J., \& Ashforth, B. E. (2004). Employability: a psycho-social construct, its dimensions, and applications. Journal of Vocational Behavior, 65(1), 14-38. doi:10.1016/j.jvb.2003.10.005.

Gegenfurtner, A., \& Vauras, M. (2012). Age-related differences in the relation between motivation to learn and transfer of training in adult continuing education. Contemporary Educational Psychology, 37(1), 33-46. doi:10.1016/j.cedpsych.2011.09.003.

Gellert, P., Ziegelmann, J. P., Lippke, S., \& Schwarzer, R. (2012). Future time perspective and health behaviors: temporal framing of self-regulatory processes in physical exercise and dietary behaviors. Annals of Behavioral Medicine, 43(2), 208-218. doi:10.1007/s12160-011-9312-y.

Hall, B. H., Mairesse, J., \& Turner, L. (2007). Identifying age, cohort, and period effects in scientific research productivity: discussion and illustration using simulated and actual data on french physicists. Economics of Innovation and New Technology, 16(2), 37-41.

Horstmanshof, L., \& Zimitat, C. (2007). Future time orientation predicts academic engagement among firstyear university students. British Journal of Educational Psychology, 77(3), 703-718. doi:10.1348/ $000709906 \times 160778$.

Hoyle, R. H. (1995). Structural equation modeling: Concepts, issues, and applications. Thousand Oaks: Sage.

Hu, L., \& Bentler, P. M. (1999). Cutoff criteria for fit indexes in covariance structure analysis: conventional criteria versus new alternatives. Structural Equation Modeling, 6(1), 1-55.

Iweins, C., Desmette, D., Yzerbyt, V., \& Stinglhamber, F. (2013). Ageism at work: the impact of intergenerational contact and organizational multi-age perspective. European Journal of Work and Organizational Psychology, 22(3), 331-346. doi:10.1080/1359432X.2012.748656.

Janeiro, I. N., \& Marques, J. F. (2010). Career coping styles: differences in career attitudes among secondary school students. International Journal for Educational and Vocational Guidance, 10(1), 35-48. doi:10. 1007/s10775-009-9170-3.

Järvelä, S. (2011). How does help seeking help? - New prospects in a variety of contexts. Learning and Instruction, 21(2), 297-299. doi:10.1016/j.learninstruc.2010.07.006.

Karabenick, S. A. (1998). Strategic Help-seeking: Implications for Learning and Teaching. Mahwah: Erlbaum.

Karabenick, S. A., \& Newman, R. S. (2006). Help Seeking in Academic Settings: Goals, Groups, and Contexts. Mahwah: Erlbaum.

Kim, D. S., \& Mo, S. H. (2014). Stereotypical beliefs on Old Korean workers. Ageing International. doi:10. 1007/s12126-014-9200-4.

Kinnunen, U., Mäkikangas, A., Mauno, S., Siponen, K., \& Nätti, J. (2011). Perceived employability: investigating outcomes among involuntary and voluntary temporary employees compared to permanent employees. Career Development International, 16(2), 140-160. doi:10.1108/13620431111115604.

Kluger, A. N., \& DeNisi, A. (1996). The effects of feedback intervention on performance: a historical review, a meta-analysis, and a preliminary feedback intervention theory. Psychological Bulletin, 119(2), 254-284. doi:10.1037/0033-2909.119.2.254.

Kooij, D. T. A. M., Bal, P. M., \& Kanfer, R. (2014). Future time perspective and promotion focus as determinants of intraindividual change in work motivation. Psychology and Aging, 29(2), 319-328.

Kubr, M. (2002). Management Consulting: A Guide to the Profession (4th ed.). Geneva: International Labour Office.

Kyndt, E., \& Baert, H. (2013). Antecedents of employees' involvement in work-related learning: a systematic review. Review of Educational Research, 83(2), 273-313. doi:10.3102/0034654313478021.

Lachman, M. E., Lewkowicz, C., Marcus, A., \& Peng, Y. (1994). Images of midlife development among young, middle-aged, and older adults. Journal of Adult Development, 1(4), 201-211. doi:10.1007/ BF02277581.

Lang, F. R., \& Carstensen, L. L. (2002). Time counts: future time perspective, goals, and social relationships. Psychology and Aging, 17(1), 125-139. doi:10.1037//0882-7974.17.1.125.

Lazarus, R. S., \& Folkman, S. (1984). Stress, Appraisal, and Coping. New York: Springer. 
Lee, F. (1997). When the going gets tough, do the tough ask for help? Help seeking and power motivation in organizations. Organizational Behavior and Human Decision Processes, 72(3), 336-363.

Little, T. D., Cunningham, W. A., Shahar, G., \& Widaman, K. F. (2002). To parcel or not to parcel: exploring the question, weighing the merits. Structural Equation Modeling, 9(2), 151-173. doi:10.1207/ S15328007SEM0902 1.

Mäkitalo-Siegl, K., \& Fischer, F. (2011). Stretching the limits in help-seeking research: theoretical, methodological, and technological advances. Learning and Instruction, 21(2), 243-246. doi:10.1016/j. learninstruc.2010.07.002.

Marsick, V. J. (2009). Toward a unifying framework to support informal learning theory, research and practice. Journal of Workplace Learning, 21(4), 265-275. doi:10.1108/13665620910954184.

Maurer, T. J., Weiss, E. M., \& Barbeite, F. G. (2003). A model of involvement in work-related learning and development activity: the effects of individual, situational, motivational, and age variables. Journal of Applied Psychology, 88(4), 707-724. doi:10.1037/0021-9010.88.4.707.

Meyers, R., Billett, S., \& Kelly, A. (2010). Mature-aged workers' learning needs and motivations for participation in training programs. International Journal of Training Research, 8(2), 116-127. doi:10. 5172/ijtr.8.2.116.

Midtsundstad, T. I., \& Bogen, H. (2014). Active aging policies between individual needs and collective goods. A study of active aging policies and practices in Norway. Nordic Journal of Working Life Studies, 4(2), $139-158$.

Miller, R. B., \& Brickman, S. J. (2004). A model of future-oriented motivation. Educational Psychology, $16(1)$.

Miner-Rubino, K., Winter, D. G., \& Stewart, A. J. (2004). Gender, social class, and the subjective experience of aging: self-perceived personality change from early adulthood to late midlife. Personality \& Social Psychology Bulletin, 30(12), 1599-1610. doi:10.1177/0146167204271178.

Muthén, L. K., \& Muthén, B. O. (2012). MPlus. Los Angeles: Muthén \& Muthén.

OECD. (2012). OECD Environmental Outlook to 2050. Paris: OECD Publishing. doi:10.1787/ 9789264122246-en.

OECD. (2014). OECD.Stat Database. doi:10.1787/20752342

Patrickson, M., \& Ranzijn, R. (2003). Employability of older workers. Equal Opportunities International, 22(5), 50-63. doi:10.1108/02610150310787496.

Petersitzke, M., \& Hristozova, E. (2006). Managing Employability in the German Consultancy Industry. In M. E. Domsch \& E. Hristozova (Eds.), Human Resource Management in Consulting Firms (pp. 191-211). Berlin: Springer.

Phalet, K., Andriessen, I., \& Lens, W. (2004). How future goals enhance motivation and learning in multicultural classrooms. Educational Psychology Review, 16(1), 59-89. doi:10.1023/B:EDPR. 0000012345.71645.d4.

Pintrich, P. R., \& Zusho, A. (2002). The Development of Academic Self-regulation: The Role of Cognitive and Motivational Factors. In A. Wigfield \& J. S. Eccles (Eds.), Development of Achievement Motivation (pp. 249-284). San Diego: Academic. doi:10.1016/B978-012750053-9/50012-7.

Podsakoff, P. M., \& Organ, D. W. (1986). Self-reports in organizational research: problems and prospects. Journal of Management, 12(4), 531-544. doi:10.1177/014920638601200408.

Podsakoff, P. M., Ahearne, M., \& Mackenzie, S. B. (1997). Organizational citizenship behavior and the quantity and quality of work group performance. Journal of Applied Psychology, 82(2), 262-270.

Raemdonck, I., Beausaert, S. A. J., Froehlich, D. E., Kochoian, N., \& Meurant, C. (2015). Age related changes in learning and employability. In D. Rosseau, D. T. A. M. Kooij, \& P. M. Bal (Eds.), Aging Workers and the Employee-Employer Relationship (pp. 163-184).

Rodriguez, D., Patel, R., Bright, A., Gregory, D., \& Gowing, M. K. (2002). Developing competency models to promote integrated human resource practices. Human Resource Management, 41(3), 309-324. doi:10. 1002/hrm.10043.

Sanders, J., \& De Grip, A. (2004). Training, task flexibility and low-skilled workers' employability. International Journal of Manpower, 25(1), 73-89. doi:10.1108/01437720410525009.

Simons, J., Vansteenkiste, M., Lens, W., \& Lacante, M. (2004). Placing motivation and future time perspective theory in a temporal perspective. Educational Psychology Review, 16(2), 121-139. doi:10.1023/B:EDPR. 0000026609.94841.2f.

Staudinger, U. M., \& Bowen, C. E. (2011). A systemic approach to aging in the work context. Zeitschrift für ArbeitsmarktForschung, 44(4), 295-306. doi:10.1007/s12651-011-0086-2.

Stewart, A. J., Ostrove, J. M., \& Helson, R. (2001). Middle aging in women: patterns of personality change from the 30 s to the 50s. Journal of Adult Development, 8(1), 23-37. 
Van der Heijde, C. M., \& Van der Heijden, B. I. J. M. (2006). A competence-based and multidimensional operationalization and measurement of employability. Human Resource Management, 45(3), 449-476. doi:10.1002/hrm.20119.

Van der Heijden, B. I. J. M., Boon, J., Van der Klink, M. R., \& Meijs, E. (2009). Employability enhancement through formal and informal learning: an empirical study among Dutch non-academic university staff members. International Journal of Training and Development, 13(1), 19-37. doi:10.1111/j.1468-2419. 2008.00313.x.

Van der Klink, M. R., Van der Heijden, B. I. J. M., Boon, J., \& Williams van Rooij, S. (2014). Exploring the contribution of formal and informal learning to academic staff member employability. Career Development International, 19(3), 337-356. doi:10.1108/CDI-03-2013-0030.

Van der Rijt, J., Van den Bossche, P., Van de Wiel, M. W. J., Segers, M. S. R., \& Gijselaers, W. H. (2012). The role of individual and organizational characteristics in feedback-seeking behaviour in the initial career stage. Human Resource Development International, 15(3), 283-301. doi:10.1080/13678868.2012. 689216.

Van Emmerik, H., Schreurs, B., De Cuyper, N., Jawahar, I. M., \& Peeters, M. C. W. (2012). The route to employability: examining resources and the mediating role of motivation. Career Development International, 17(2), 104-119. doi:10.1108/13620431211225304.

Walker, A., \& Maltby, T. (2012). Active ageing: a strategic policy solution to demographic ageing in the European Union. International Journal of Social Welfare, 21, S117-S130. doi:10.1111/j.1468-2397.2012. 00871.x.

Wright, P. M., \& Snell, S. A. (1998). Toward a unifying framework for exploring Fit and flexibility in strategic human resource management. Academy of Management Review, 23(4), 756-772.

Zacher, H., Heusner, S., Schmitz, M., Zwierzanska, M. M., \& Frese, M. (2010). Focus on opportunities as a mediator of the relationships between age, job complexity, and work performance. Journal of Vocational Behavior, 76(3), 374-386. doi:10.1016/j.jvb.2009.09.001.

Dominik Emanuel Froehlich is currently working as a $\mathrm{PhD}$ researcher at Maastricht University, Department for Educational Research and Development. His work focuses on aging workers and how they may maintain and improve their employability by the means of formal and informal learning. He especially investigates information, feedback, and help seeking within the employees' social network.

Simon Beausaert is an assistant professor at the Faculty of Psychology and Educational Sciences, Université Catholique de Louvain-la-Neuve and the Department for Educational Research and Development, Maastricht University. He is the project coordinator of a research project focusing on the informal learning of aging employees. His fields of interests are: professional development, assessment for learning, performance interviews and personal development plans, learning of aging employees, teacher education and problem based learning.

Mien Segers is Professor Corporate Learning at the department of Educational Research and Development. Her research addresses tools and conditions to support learning in school settings as well as in the workplace, with a special focus on the role of assessment for enhancing development. She is actively involved in the European Association for Research on Learning and Instruction (EARLI) and has been the coordinator of the Special Interest Groups Higher Education and Assessment. She has been publishing in many high-ranked journals and is an editorial board member of international journals such as Studies in Educational Evaluation and Educational Research Review. She is the chief-editor of the EARLI Book Series 'New Perspectives on Learning and Instruction'. 